\title{
Assessment of the patients diagnosed with conversion disorder in the emergency department
}

\section{Acil serviste konversiyon bozukluğu tanısı alan hastaların değerlerdirilmesi: Retrospektif, gözlemsel bir çalışma}

\author{
Togay Evrin ${ }^{1}$, Eylem Kuday Kaykısı² \\ ${ }^{1}$ Department of Emergency Medicine, Ufuk University Dr. Ridvan Ege Research and Trainig Hospital, Ankara, Turkey \\ ${ }^{2}$ Department of Emergency Medicine, Bitlis State Hospital, Bitlis, Turkey \\ Geliş Tarihi:31.07.2017 \\ Kabul Tarihi:27.08.2017 \\ Doi: $10.21601 /$ ortadogutipdergisi.449211
}

\begin{abstract}
Aim: Conversion disorder is defined as a specific disorder that accompanies the psychological conflict, has one or more neurological symptoms and in which there is a loss of bodily functioning that would seem to a physical disturbance. The aim of this study was to determine the ratio of the patients diagnosed with conversion disorder to all patients in the emergency department and to investigate the sociodemographic and clinical characteristics of the patients, attitudes and treatment approaches of the physicians.

Material and Method: This cross sectional, retrospective study was conducted at a governmental secondary care hospital. After approval from the ethics committee, data pertaining to patients aged at least 18 years who had presented to the ED with various symptoms and had diagnosis of conversion was studied between July 1 and December 31,2017 . The exclusion criteria were as follows: age of less than 18 years, patients with additional pathology besides conversion disorder, patients with a lack of psychiatric consultation and patients whose data cannot be accessed from the system. A p value less than 0.05 was considered statisticallysignificant.

Results: A total of 124 patients were included in the study. 71\% (n: 88) of the patients were female, 54.8\% (n: 68) were single. $17.7 \%(\mathrm{n}=22)$ of the patients had comorbid disease. There was a stressor event in all patients before hospital admission. $\% 50$ of patients were younger than 23 years. The most common complaint was syncope. 93 patients admitted by ambulance. There was the prior conversion disorder history in $66.1 \%$. Any medical examinations were not required in $61.3 \%$ of the patients. The mean elapsed time in all patients was $135 \mathrm{~min}$. Between in patients transported by ambulance and in walk-in patients, there was a statistically significant difference in terms of mean elapsed time between the patients' emergency service admission and discharge from hospital.
\end{abstract}

Conclusion: It was detected that the conversion disorder was more commonly seen in female gender and young age group, the most common complaint of conversion disorder was syncope, most of the patients with conversion disorder had similar complaints before, patients with conversion disorder often preferred to transport to the hospital with ambulance, the patients who received the red code according to the triage code and patients with conversion disorder were examined in almost the same time period and the patients with conversion disorder stayed in emergency department for long hours.

Keywords: Conversion disorders, emergency department, somatoform disorders 


\section{Öz}

Amaç: Konversiyon bozukluğu; psikolojik çatışmaya eşlik eden, fiziksel bir bozukluğu düşündürecek biçimde bedensel işlevsellikte kayıplarla giden, bir ya da daha fazla nörolojik semptomla belirli bozukluk olarak tanımlanmaktadır. Bu çalışmanın amacı konversiyon bozukluğu tanısının acil serviste ne kadar yer bulduğu; hastaların sosyodemografik ve klinik özellikleri ve hekim tutum ve tedavi yaklaşımlarını incelemekti.

Gereç ve Yöntem: Bu retrospektif, kesitsel çalışma, 2. basamak bir devlet hastanesinde gerçekleştirilmiştir. Etik kurul onayı sonrasında, 1 Temmuz- 31 Aralık 2017 tarihleri arasında, çeşitli semptomlarla acil servise başvuran ve konversiyon bozukluğu tanısı alan 18 yaş üstü hastalar, çalışmaya dahil edilmiştir. Dışlama kriterleri; hastanın 18 yaş altı olması, hastada konversiyon bozukluğu yanında ek patoloji tespit edilmiş olması, hastanın psikiyatri konsultasyonu olmaması ve sistemden hasta verilerine ulaşılamaması olarak belirlenmiştir. $p<0.05$ değeri istatistiksel anlamlı kabul edilmişsir.

Bulgular: Toplam 124 hasta çalışmaya dahil edildi. Hastaların \%71'I kadın ve \%54,8'i bekar; \%17,7'sinin komorbid hastalığı mevcuttu. Tüm hastalarda hastane başvurusu öncesi bir stres maruziyeti mevcuttu. Hastaların \%50'si 23 yaş altıydı. En s1k başvuru şikayeti senkoptu. 93 hasta ambulans ile başvurmuştu. \%66,1 hastada daha önceden konversiyon bozukluğu öyküsü mevcuttu. Hastaların \%61,3'ünde herhangi bir tetkik gerekmemişti. Ortalama taburculuk süresi 135 dakikaydı. Hastaneye ambulansla başvuranlar ile ayaktan başvuran hastalar arasında, ortalama taburculuk süresi açısından istatistiksel anlamlı bir fark mevcuttu.

Sonuç: Konversiyon bozukluğunun; kadın cinsiyet ve genç yaş grubunda daha sık görüldüğü; en sık başvuru şikayetinin senkop olduğu; hastaların büyük kısmının daha önce de benzer şikayetleri olduğu; hastaların sıklıkla ambulans ile hastaneye başvuruyu tercih ettikleri; triaj koduna göre kırmızı kod alan hastalar ile hemen hemen aynı süreler içinde muayene edildikleri ve uzun saatler acil serviste kaldıkları sonuçlarına ulaşılmıştır.

Anahtar Kelimeler: Konversiyon bozukluğu, acil servis, somatoform bozukluklar

\section{Introduction}

Conversion disorder is defined as a specific disorder that accompanies the psychological conflict, has one or more neurological symptoms and in which there is a loss of bodily functioning that would seem to a physical disturbance. It is located under the heading of somatoform disorders in DSM-IV, and under the heading of dissociative disorders in ICD-10 [1]. Four types of conversion disorder are specified as type with motor symptoms, type with sensory symptoms, type with contractions and type with mixed presentation.Patients often admit to the emergency service due to the syncope and mutism complaints developing following a stressful situation. A patient admitting with these symptoms should be considered a neurological patient until it is proven otherwise.For diagnosing in these patients, the detailed story should be taken, neurological and physical examination should be done and the required radiological and biochemical examinations should be completed. If there is no organic cause, the patients should be consulted to psychiatrist by combining the stressor story and the disease.If it is considered that there is no organic disease and the diagnosis is thought to be psychiatric, the treatment is not urgent. Psychiatric treatment of these patients is not performed in emergency departments.Nevertheless, psychiatric emergency services performed with effective measures in a limited period of time, can provide minimize loss from the physical and psychological burden of the disease for the both patient and patient relatives as a result of fast and correct orientation of patients.A successful first aid will facilitate the patient's compliance with the subsequent treatments in addition to preventing the second emergency situation [2].

$3-12 \%$ of the patients examined in emergency departments of hospitals are diagnosed with psychiatric pre-diagnosis [2]. Since the approach to conversion disorder varies due to the differences of the emergency physicians' personality traits, types of training and sociocultural, there is no clear approach.

The aim of this study was to determine the ratio of the patients diagnosed with conversion disorder to all patients in the emergency department and to investigate the sociodemographic and clinical characteristics of the patients, attitudes and treatment approaches of the physicians. 


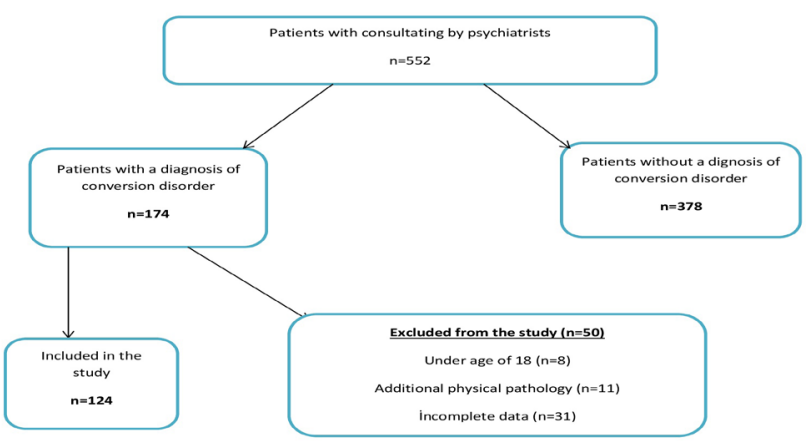
committee of Bitlis Eren University (10/04/2018-3629-V), Turkey, data pertaining to patients aged at least 18 years who had presented to the ED with various symptoms and had diagnosis of conversion disorders (as determined via consultation by psychiatristswho was blinded to the study protocol after history taking and physical examination) was studied. Data including sex, age, marital status, concomitant diseases, complaint of admission, type of admission to the hospital (via 112 or outpatient), prior conversion disorder diagnosis, prior stressor factor, whether or not an examination is required, if an examination is required, the type of examination required, whether or not a treatment is given and given treatment type, duration of examination, duration of discharge, were recorded from the computerized system of the hospital. The exclusion criteria were as follows: age of less than 18 years, patients with additional pathology besides conversion disorder, patients with a lack of psychiatric consultation and patients whose data cannot be accessed from the system.

\section{Statistical Analysis}

Statistical analysis was performed with the SPSS 22.0 Statistical Package for Windows (SPSS Inc, Chicago, IL, USA). The median and standard deviation of the continuous variables were given, and the categorical variables were defined as percentages. The differences between groups werecompared by using Mann-Whitney U-test where appropriate. Data were shown as mean \pm standarddeviation or median (min-max), where applicable. A p value less than 0.05 was considered statisticallysignificant.

\section{Results}

During the study period, 174 out of 552 patients who underwent psychiatric consultation were diagnosed with the conversion disorder. A total of 124 patients were included in the study and 50 patients excluded from the study. Flow of participants is shown in figure-1 (fig 1). 71\% (n: 88) of the patients were female, $54.8 \%$ (n: 68 ) were single. $17.7 \%$ $(n=22)$ of the patients had comorbid disease.

Figure 1. Flow of participants.

There was a stressor event in all patients before hospital admission. When the distribution of comorbid diseases were investigated; epilepsy in 12 patients, Pregnancy in 5 patients, DM in 2 patients and HT in 3 patients were seen. Futhermore, 4 of the pregnant and / or epileptic patients had anemia as an addition. Mean age of patients was 30,4 (18-74), and there was a statistically significant decrease in the mean age of male patients $(\mathrm{p}=0.003)$. When the age distribution of the patients was examined, it was detected that $50 \%$ of the patients were younger than 23 years, the rate of patients over 50 years old was $6.5 \%$ and rate of patients over 60 years old was $2 \%$.

When the admission complaints of patients were evaluated, the most common complaint was syncope with $58 \%$ $(n=72)$. Followed by chest pain and palpitation with $13 \%$, contractions with $10 \%$, trembling with $7 \%$. 16 patients admitted to hospital due to other complaints (mutism, headache, numbness in hands and feet, etc.).

When the time elapsed between the patients' admission to the emergency service and examination was evaluated, it was seen that the mean elapsed time in all patients was 4.25 (115) min, the mean elapsed time was 5 minutes in the walk-in patients and the mean elapsed time was 4 minutes in patients transported by ambulance. This elapsed time was statistically lower in patients trasported by ambulance $(\mathrm{p}=0.015)$.

When it was examined how the patients came to emergency department, it was seen that 93 patients $(75 \%)$ came by ambulance and 31 (25\%) patients came by foot. There was the prior conversion disorder history in $66.1 \%(n=82)$ patients.Any medical examinations were not required in $61.3 \%(n=76)$ of the patients. Examination distributions of patients are shown in Figure-2a. When the rates of requested examinations examined according to modes of arrival (via ambulance or on foot), there was no statistically significant difference between the groups $(\mathrm{p}=0.095)$. 


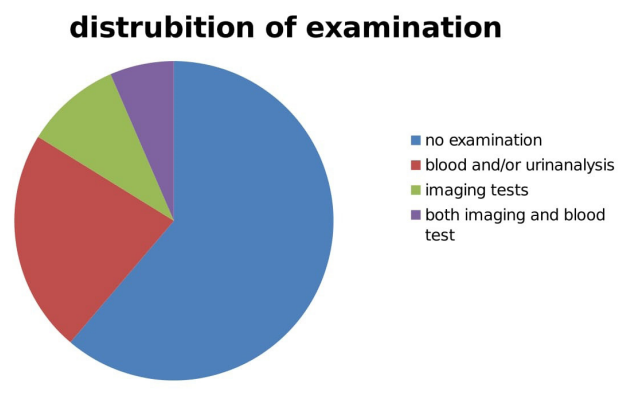

Figure 2a. Distributions of patients.

When the treatments of the patients were evaluated, it was seen that $16(12.9 \%)$ patients did not receive any treatment. The treatment distributions of the patients are shown in Figure- $2 b$.

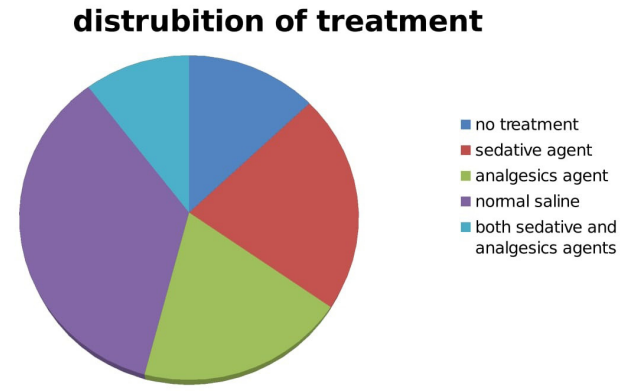

Figure 2b. The treatment distributions of the patients.

When the elapsed time between the patients' emergency service admission and discharge from hospital was evaluated; the mean elapsed time in all patients was $135 \mathrm{~min}$ (20-500 min), this elapsed time is 110 minutes (20-500) in patients transported by ambulance; and 160 minutes (60400 ) in walk-in patients. Between two groups, there was a statistically significant difference in terms of mean elapsed time between the patients' emergency service admission and discharge from hospital $(\mathrm{p}<0.001)$ (Table 1).

\begin{tabular}{|c|c|c|c|c|}
\hline \multicolumn{3}{|c|}{ Characteristics of participants } & $\begin{array}{l}\text { number of } \\
\text { patients(n) }\end{array}$ & $\begin{array}{c}\text { percent } \\
(\%)\end{array}$ \\
\hline \multirow{2}{*}{ Sex } & \multicolumn{2}{|c|}{ female } & 88 & $\% 71$ \\
\hline & \multicolumn{2}{|c|}{ male } & 36 & $\% 29$ \\
\hline \multirow{2}{*}{ Marital status } & \multicolumn{2}{|c|}{ marriage } & 56 & $\% 45.2$ \\
\hline & \multicolumn{2}{|c|}{ single } & 68 & $\% 54.8$ \\
\hline \multirow{6}{*}{$\begin{array}{l}\text { Concomitant } \\
\text { disease }\end{array}$} & \multirow{5}{*}{$\begin{array}{c}\text { yes } \\
\text { n:22 } \\
(17.7 \%)\end{array}$} & epilepsy & 12 & $\% 10$ \\
\hline & & pregnancy & 5 & $\% 4$ \\
\hline & & $\begin{array}{l}\text { diabetes } \\
\text { mellitus }\end{array}$ & 2 & $\% 2$ \\
\hline & & $\begin{array}{l}\text { hyperten- } \\
\text { sion }\end{array}$ & 3 & $\% 3$ \\
\hline & & anemia & 4 & $\% 4$ \\
\hline & \multicolumn{2}{|c|}{ no } & 102 & $\% 82.3$ \\
\hline \multirow{5}{*}{$\begin{array}{l}\text { Complaint of } \\
\text { admission }\end{array}$} & \multicolumn{2}{|c|}{ syncope } & 72 & $\% 58$ \\
\hline & \multicolumn{2}{|c|}{$\begin{array}{c}\text { chest pain/palpita- } \\
\text { tions }\end{array}$} & 16 & $\% 13$ \\
\hline & \multicolumn{2}{|c|}{ spasm } & 12 & $\% 10$ \\
\hline & \multicolumn{2}{|c|}{ tremble } & 8 & $\% 7$ \\
\hline & \multicolumn{2}{|c|}{ others } & 16 & $\% 13$ \\
\hline \multirow{2}{*}{$\begin{array}{l}\text { Route of admis- } \\
\text { sion }\end{array}$} & \multicolumn{2}{|c|}{ via ambulance } & 93 & $\% 75$ \\
\hline & \multicolumn{2}{|c|}{ outpatient } & 31 & $\% 25$ \\
\hline \multirow{2}{*}{$\begin{array}{l}\text { Prior conver- } \\
\text { sion disorder } \\
\text { history }\end{array}$} & \multicolumn{2}{|c|}{ yes } & 82 & $\% 66.1$ \\
\hline & \multicolumn{2}{|c|}{ no } & 42 & $\% 33.9$ \\
\hline
\end{tabular}

\section{Discussion}

Patients with conversion disorder often and especially admit to emergency services at the first attacks [3]. The most of emergency physicians arrive to the diagnosis of these patients clinically after a history, full physical examination and, if necessary, examinations. However, in developing countries where the patient admissions are much higher than the workforce and possibilities, the evaluation of the patients with conversion disorder takes time and physicians often can not spare time to the mental distresses of these patients.

In one study, it was found that approximately $10 \%$ of patients diagnosed with psychiatric diagnoses in the emergency department were diagnosed with conversion disorder [4]. In the same study, it was reported that about $30 \%$ of these patients admitted to the emergency service again and $85.3 \%$ of the first and second admissions were out 
of work hours. This result was supported by other studies [5]. This situation was associated with the intensive work of the patients during the day and the belief that secondary earnings would be better provided by the patients when family members came together after working hours. The readmission rates of patients and the timing of the patients' hospital admissions were not evaluated in our study.This may be another study subject. From all these angles, the importance of the morbidity, cost, and workforce loss in patients and their relatives caused by psychiatric disorders once again appears.

The presenting symptoms and other features of emergency department patients with conversion disorder show difference according to their cultures and socioeconomic status [6].The most frequent admission symptoms of patients diagnosed with conversion disorder in our country were reported as syncope, paresthesia, contractions, tremors and mutism [3]. Apart from these, many symptoms such as loss of sense, swallowing difficulties, convulsions was reported [7]. In a study where the admission symptoms of patients were investigated, it was reported that 52.3\% of patients had syncope, $22.1 \%$ had dyspnea, $\% 18,6$ had paralysis [8]. In our study, the most common admission symptoms were syncope, chest pain and palpitation, contraction, tremor in accordance with the literature. In addition, mutism, headache, numbness in hands and feet were also among admission symptoms.

Conversion disorder is seen in all age groups, but it is most commonly seen in the 15-35 age group [9]. In a study conducted in our country, it was reported that the mean age was $29.2+-10.8$ and there was statistically significant lower in the mean age of male patients than that of females $[10,11]$. In also our study, the mean age was 23.5 , and the mean age of male patients was significantly lower than that of female patients and is consistent with this literature. The great majority of patients diagnosed with conversion disorder consist of female patients. It was reported in various studies that the ratio of female/male changed between 2-7 [8,10,12,13]. When the patients were evaluated according to the age group, there were many studies which reported that the male and female ratio in pre-adolescence patients was equal and this ratio increased to 19 times after puberty [14]. In our study, $70 \%$ of the patients consisted of female patients, in accordance with the literature. However, since the study population was not under 18 years of age, it was not possible to compare the male and female ratio in adolescent patients.

In our study, it was detected that the $45.2 \%$ of patients were married. In study by Uguz et al., it was reported that this rate was $\% 69.5$. In another study conducted in our country, it was reported that $79.1 \%$ of female patients and $80 \%$ of male patients were married [8]. In studies carried out abroad, this rate was between $40.6 \%$ and $60 \%$ [15]. The rate of married patients in our study is lower according to our country data. This is thought to be due to the fact that $50 \%$ of the patients in the study were younger than 23 years of age.In parallel with today's socioeconomic and cultural development, the increase was seen in the population studying at university, and young people in this population usually do not marry. Onthe other hand, conversion disorder is a disease seen in young age. When these are taken into consideration, it is thought that the rate of single patients in our study is higher than those in the past.Looking at overseas data, it was seen that the rate of single patients was higher in parallel with the development. The incidence of conversion disorder is 1-3\% in developed countries while the incidence is $10 \%$ in developing countries [16]. In our country, this rate was reported in a wide range of $4.5 \%-32 \%$ [17]. However, these rates indicated the conversion disorder incidence in the community. The population in our study only included the emergency department patients.In a study conducted by Serinkan et al, it was reported that the diagnosis rate of conversion disorder in emergency department was 3.67 in the university hospital and 2.53 in the state hospital [10]. If it was taken into consideration that the number of 6-month emergency department admissions in our study is 90000 , it was found that the incidence of conversion disorder was $1.94 \%$. The cause of the this rate that was lower in our study than the other studies may be that the patients who were diagnosed with conversion disorder by only psychiatrists were included in this rate because of the retrospective nature of the study.It should not be forgotten that the patients whose conversion disorder is diagnosed by emergency physician and not consulted may exist.

It was shown that the low socioeconomic conditions, low educational level, impaired insight, low intelligence level, female gender and young age were in the conversion disorder risk factors $[14,18]$. It should be also important to not ignore the importance of pre-disease stress factors. 
In the studies carried out in our country, It is known that pre-conversion stress factors are seen in rate of $17-45 \%$ $[9,19]$. The point to note here is that conversion disorder may become permanent after first attack of conversion. In $90 \%$ of the patients the symptoms start after stress and improve within 1 month.In a similar study, it was reported that $75 \%$ of the patients had no re-attack and $25 \%$ of the patients had re-attack throughout stressful life periods [16]. In our study, it was seen that there was a stressor factor in all patients after examination of psychiatric consultations.Many factors such as low socioeconomic level, job finding anxiety, forced marriage in women, and terrorist incidents can participate in the stressors events. There are studies reporting that especially conditions such as terrorist attacks can lead to post traumatic stress disorder and conversion disorder [20]. After conversion disorder occurring after any of these situations, the conversive situation can become chronic because of some secondary gains such as taking over the responsibilities of patient by a family member and making things easier for the patient. Because of the retrospective nature of our study, patients' recovery or chronicity state were not followed.

Other medical causes must be excluded before the diagnosis of conversion disorder in emergency departments. It is known that $25-50 \%$ of all conversion disorder diagnoses develop with other medical reasons.The physician should carefully exclude the underlying general medical condition in undiagnosed patients, conditions caused by substance use, another mental state responsible for somatic symptoms, the situations such as stimulation and factitious disorder where non-existent symptom is shown as if it exists [21]. In our study, any examination were performed to $38.7 \%$ of the patients and these examinations included one or more of blood test, urinalysis, and imaging methods. In literature, it was seen that there was no study showing what the rate of examinations was in the conversion patients. This situation can be attributed to the fact that organic etiology must be absolutely exluded in patients before diagnosis and the theoretical rate of examination should be $100 \%$. This situation can be attributed to the fact that organic etiology must be absolutely exluded in patients before diagnosis and the theoretical rate of examination should be $100 \%$. These low rates in our study may be related to the intensity of the emergency department and the patients diagnosed without any examinations because of the obvious symptoms and findings.In studies where the emergency psychiatric admissions were examined, it was seen that the most common diagnoses were somatoform disorder, especially conversion disorder. In a study conducted in 2002, it was reported that $12.9 \%$ of emergency department admissions made during 1 year consisted from psychiatric cases, but only $12-25 \%$ of these cases were a true psychiatric emergency [22].

In a study for evaluation aim of the admissions to emergency ambulance services conducted by Aker et al in 2004, it was found that $12,13 \%$ of the 9015 admissions made in the related period were caused by psychiatric diseases, the most frequent complaint was syncope (48.1\%) and the most common diagnosis after the examination was conversion disorder (62.6\%) in both genders.Moreover, it was seen that this rate increased to $74 \%$ in female patients [23]. In a study conducted by Yaylac1 et al., it was found that there was no significant difference in duration of staying at emergency service between the patients who admitted to the emergency service with the ambulance and the patients who did not come with the ambulance [24]. In some studies, it was shown that $60 \%$ of patients with psychiatric disorder admitting to emergency department were misdiagnosed and not properly treated [25-27]. Patients' unnecessary admissions to emergency department cause excessive intensity in hospitals. This excessive intensity leads to the long of the patient waiting period, delay in service to patients who had serious ailment and need urgent intervention, an increase in dissatisfaction of patients in emergency department, a decrease in quality of service, the problems about safety of both the patient and the treatment team. The common result of all these reasons is the decline in personnel productivity. Public education that will be organized to reduce unnecessary emergency service admissions may contribute to this issue. Public service announcement can also support the public education. Educating relatives of patients with conversion disorder about approach to patient, especially during an attack will reduce unnecessary causes of emergency department intensity and workload.

\section{Study Limitations}

Some limitations exist in our study. The first limitation is that it is not known at which time intervals the patients frequently admitted to emergency services. Because this time interval affects the mean examination time. The 
second limitation is the absence of data about whether the patients were hospitalized or were discharged after their admissions to the emergency department. Patients arriving with ambulance who left emergency department more quickly may be attributed to the condition in which the patients were hospitalized.Another limitation is that it is not known whether the treatments administered to patients are performed before or after the psychiatric consultation. Therefore, the responsibilities of the emergency physician in the approach to the patient with conversion disorder cannot be determined.In this subject, multi-center, prospective studies conducted with wider patient groups are needed.

\section{Conclusion}

In our study, it was detected that the conversion disorder was more commonly seen in female gender and young age group, the most common complaint of conversion disorder was syncope, most of the patients with conversion disorder had similar complaints before, patients with conversion disorder often preferred to transport to the hospital with ambulance, the patients who received the red code according to the triage code and patients with conversion disorder were examined in almost the same time period and the patients with conversion disorder stayed in emergency department for long hours.

Funding and support: No need to supported financially.

Informed Consent: Written informed consent form was obtained from all the participants of the study.

Conflict of interest: All authors declare that they have no conflict of interest.

Author Contributions: TE Study concept and desing, acqusition of data, critical revision of the manuscript for important intellectuel content, statistical analysis, technical and material support; EKK: analysis and interpretation of data, drafting of the manuscript study concept and desing, study supervision and both authors contributed substantially to its revision and approved the final version of the study.

Ethical approval: All procedures performed in studies involving human participants were in accordance with the ethical standards of the institutional and/or national research committee and with the 1964 Helsinki declaration and its later amendments or comparable ethical standards. This article does not contain any studies with animals performed by any of the authors.

\section{References}

1. Okasha A. Somatoform disorders revisited. Acta Neuropsychiatrica 2003; 15: 161-6.

2. Bekaroglu M, Bilici M. Psikiyatrik Aciller. İçinde: Gülec C, Köroğlu E, editör. Psikiyatri Temel Kitabı. 2. Cilt. Ankara: Hekimler Yayın Birliği; 1998. S. 835-55.

3. Bediz U, Aydemir C, Başterzi AD, Kısa C, Cebeci S, Goka E. Hekimlerin konversiyon bozukluğuna yaklaşımını etkileyen faktörler. Klinik Psikiyatri Derg 2004; 7:73-9. .

4. Bahçeci B, Güveli H, Kandemir G, Aslan M, Köroğlu A. Erişkin acil servisinde psikiyatri dışı hekimlerce konulan psikiyatrik ön tanıların değerlendirilmesi. J Kartal TR 2011; 22: 65-9.

5. Kısa C, Aydın OD, Cebeci S, Aydemir Ç, Göka A. Acil psikiyatrik başvuruların ve acil psikiyatrik hizmetlerin değerlendirilmesi. New/Yeni Symposium J1 2001; 39: 174-80.

6. Dula DJ, DeNaples L. Emergency department presentation of patients with conversion disorder. Acad Emerg Med 1995; 2: 120-3.

7. Özmen E. Genel tıpta somatizasyon. In: Özmen E, Aydemir O, Bayraktar E, editors. Genel Tipta Psikiyatrik Sendromlar. Ankara: Hekimler Yayın Birliği; 1997.p.235-61.

8. Özen S, Özbulut O, Altındag A, Arıcıogulları Z. Acil serviste konversiyon bozukluğu tanısı konan hastaların sosyodemografik özellikleri, stres faktörleri, I. Ve II. Eksen eş tanıları. Türkiye'de Psikiyatri 2000; 2: 87-97.

9. Chandrasekaran R, Goswami U, Sivakumar V, Chi-tralekha. Hysterical neurosis--a follow-up study. Acta Psychiatr Scand 1994; 89: 78-80

10. Serinken M, Sengül C, Karcioglu Ö, Zencir M. Acil Serviste "Konversiyon Reaksiyonu" Tanısı Alan Hastaların Klinik ve Demografik Özellikleri. TurkJ Emerg Med 2007; 7: 5-9.

11. Deveci A, Özmen E, Demet MM, Bir üniversite hastanesi psikiyatri polikliğine başvuran konversiyon bozukluklu hastaların sosyodemografik ve klinik özellikleri. Anadolu Psikiyatri Derg $2002 ; 3: 28-33$

12. Mai FM. "Hysteria" in clinical neurology. Can J Neurol Sci 1995; 22: $101-10$

13. Uğuz Ş, Toros F. Konversiyon bozukluğunda sosyodemografik ve klinik özellikler. Türk Psikiyatri Derg 2003; 14: 51-8.

14. Bhatia MS, Vaid L. Hysterical aphonia- an analysis of 25 cases. Indian J Med Sci 2000; 54: 335-8.

15. Kent DA, Tomasson K, Coryell W. Course and outcome of conversion and somatization disorders. A four year follow up. Psychosomatics 1995; 36; 138-44. 
16. Kaplan HI, Sadock BJ, Grebb JA. Somatoform Disorders. Williams and Wilkins. Synopsis of Psychiatry. 7. Bask1, Baltimore, 1994. p.617-32.

17. Sağduyu A, Rezaki M, Kaplan Đ, Özgen G, Rezaki BG. Sağlık ocağına başvuran hastalarda disosiyatif (konversi-yon) belirtiler. Türk Psikiyatri Derg 1997;8:161-9. .

18. Alkın T, Tunca Z. Konversiyon bozukluğu. Güleç C, Köroğlu E, editörler. Psikiyatri Temel Kitabı. 2. Baskı. Ankara: Hekimler Yayın Birliği; 1998. p.537-44.

19. Ersoy MA. Şüpheli bir konversiyon bozukluğu olgusu: konversiyon bozukluğunun psikiyatrik olmayan diğer t`bbi durumlarda ilişkisi. Psychomed 1995; 1: 111-4.

20. Evrin T, Demirel B, Y1lmaz B, et al. Post-traumatic stress disorder after terrorist attack in healthcare professionals. Disaster Emerg Med J 2017; 2: 11-8.

21. Allan Frances MD, Ruth Ross MA. Somatoform bozukluklar DSMIV-TR Olgu Sunumları ayırıcı tanı için Klinik Klavuz 1. Baskı. İstanbul: Vedat Şar CSA Medikal Yayın Ajansı; 2001. P 191-2.

22. Kropp S, Andreis C, Wildt B, Sieberer M, Ziegenbein M, Huber TJ. Characteristics of psychiatric patients in the accident and emergency department. Psychiat Prax 2007; 34: 72-5.

23. Aker S, Böke Ö, Peşken Y. "112 Acil Sağlık Hizmetine Başvurulardaki Psikiyatrik Olguların DeğerlendirilmesiSamsun-2004”, Anadolu Psikiyatri Derg 2006; 7: 211-7.
24. Yaylacı S, Öztürk Cimilli T, Yılmazer Çelik S.Acil servise ambulansla başvuran hastaların aciliyetinin retrospektif değerlendirilmesi.Acıbadem Üniversitesi Sağlık Bilimleri Derg 2013; 4: 64-7.

25. Gill JM, Mainous AG, Nsereko M. The effect of continuity of care on emergency department use. Arch Fam Med 2000; 9: 333-8.

26. Polat O, Kabaçam G, Güler İ, Ergişii K, Yıldız A. İbn-i Sina Hastanesi Acil Servisi'ne başvuran hastaların sürveyans analizi Türkiye Acil Tıp Derg 2005; 5:78-81.

27. Küçükali Ç, Üstün Güveneroğlu N, Demirağlı Duman HB, et al. Who is seeking Emergency Care at the Emergency Psychiatric Ward of Bakırköy Mental Health and Neurological Diseases Education and Research Hospital? A cross-sectional definitive study. Anadolu Psikiyatri Derg HYPERLINK "http://www.anadolupsikiyatri.net/ index.php?jid=91\&iid=2015-16-6.000" 2015; $16: 413-9$.

Corresponding Author: Eylem Kuday Kaykısı,, Department of Emergency Medicine, Bitlis State Hospital, 13000, Bitlis, Turkey

E-mail: eylemkuday@hotmail.com

Tel: +90 5413190392 